\title{
Nutritional Status of School Going Children Age Group of 6 To 18 Years of Bhotia Tribes of Garhwal Himalaya.
}

\author{
Manwendra Singh Bartwal ${ }^{1}$, Prof. R.S.Negi ${ }^{2}$, Prof.H.B.S.Chauhan ${ }^{3}$, Prof \\ V.S.Chauhan. ${ }^{3}$ \\ 1-Post-doctoral fellow, Anthropological Survey of India, Dehradun -248195, 2-Retired Professor, 3-Professor, \\ Department of Anthropology, H.N.B.Garhwal University, Srinagar Garhwal, Uttarakhand-India, 246174.
}

\begin{abstract}
Present study is an attempt to analyse nutritional health status by the use of age and sex specific Body Mass Index thresholds of Bhotia tribal children of Garhwal Himalayas. BMI cut-off points for thinness grades 1, 2, 3 age and sex wise percentile curves passing through BMI of 16, 17, and 18.5 and for normal range of BMI of 18.5 to $23 \mathrm{~kg} / \mathrm{m} 2$ have been used to evaluate the status of children as thin, normal, overweight and obese. A total of 643 children (336 boys and 307 girls) aged $6-18$ years had participated in the present study. Bhotia tribe is one of the oldest inhabitants of mountains region of Garhwal and Kumaun, Central Himalaya. Rice and millets is the staple food of Bhotias and salty butter tea or namkeen chai (Jya) is also consumed very frequently by them, wild herbs and medicinal plants also contribute into their diets. Present study revealed that prevalence of grade-one thinness was 13.02 percent among girls and 6.84 percent among boys, Boys also having grade two and three thinness $(0.29 \%), 88.69$ percent boys and 75.24 percent girls were having normal BMI. The frequency of overweight individuals was 3.86 percent among the boys and 11.72 percent among girls, No child has been identified as obese. This is probably because the Bhotias lived in high altitude mountainous region where supplies of nutritious and surplus food through out the year is very difficult, but the girls makes a better use of food provided to them and manage to put subcutaneous fat on their body whereas boys has maintained normal health.
\end{abstract}

Keywords: Quetelet's Index; Thinness; Overweight; Bhotia; Garhwal Himalaya.

\section{INTRODUCATION:}

Body mass Index (BMI) calculated as weight (in kilograms) divided by height in meters square $(\mathrm{kg} / \mathrm{m} 2)($ Cole 1991), is one of the best indicators to assess the nutritional health status of community or an individual (WHO 1995). It is also known as Quetelet's index (Gadzik 2006) a person can be categorized as thin, normal and obese with various grades (WHO 2004). In the present study an attempt has been made to use direct age and sex specific BMI thresholds (Khadilkar et al.2012) linked to an adult Asian BMI at the age of 18 years, to see the nutritional status of the Bhotia tribal children. BMI cut-off points for thinness grades 1, 2, 3 age and sex wise percentile curves passing through BMI of 16, 17, and 18.5 (Cole et al. 2007) and for overweight and obesity (Jiang et at.2006) percentile curves passing through BMI of 23 and $28 \mathrm{~kg} / \mathrm{m} 2$ at the age of 18 years have been directly used to see the Body Mass Index of Bhotia children's of Garhwal Himalayas. Normal range of BMI of 18.5 to $23 \mathrm{~kg} / \mathrm{m} 2$, has been used to see the status of normal children's BMI (Cole et al.2000; 2007). Bhotias like to call them by their generic name viz. Marccha, Tolccha and Jad (Tolia 1998). Bhotia tribe is one of the oldest inhabitants (Dabral 2022-Vikrami) of high altitude of Garhwal and Kumaun region of Central Himalayas (Negi 1995). It is very difficult to get nutritional food throughout the year at mountainous region therefore Bhotias practiced to preserve seasonal crops, vegetables, fruits and meat for lean season (Nautiyal et al. 2003). Girl child in a family contributes in household work as well as outdoor agricultural activities to support their family. Bhotias belong to Mongoloid stock (Brown 1987); their main occupation was trade of goods between India and China but after Chinese invasions in the year 1962, this traditional trade activity has been stopped. Transhumant pastoralism is their main occupation by now (Nautiyal et al.2003); they have also started agriculture, animal husbandry in their occupied area at high and middle altitude of the Central Himalaya (Garhwal and Kumaun Himalaya). Rice and millets is their staple food and salty butter tea or namkeen chai 
(Jya) (Purohit et al.2002) is being consumed frequently by them, Wild herbs and medicinal plants (Maikhuri et al. 1998) also contribute to their diet.

\section{MATERIAL AND METHODS:}

A cross-sectional anthropometric study (McMurray 1996) for the doctoral field work was undertaken (by M.S.B.) at Chamoli and Uttarakashi Districts of Uttarakhand, during October 2004 to February 2005. This area is situated at the Indo-China international border (Atkinson 1884); Distance of the study area is approximately $330 \mathrm{~km}$ and $220 \mathrm{~km}$ respectively, from the state capital Dehradun. The place is very remote and hilly terrain makes life more difficult for Bhotias in their inhabited areas. Mostly, school and college going children (6-18 years) from Anganwadi centers, Shishu Mandir, Primary schools, High Schools and Inter-mediate College of the region, from Joshimath Block, Dasoli block and Uttarakashi block were included in the data. In addition, House visits have been made to collect household and other demographic, anthropometric or nutritional data (Malina et al.1999) a total of 643 children (336 boys and 307 girls) aged 6 - 18 years were measured. Height and weight measurements were taken on each subject following the standard techniques (Weiner and Lourie 1981). Weight was measured using spring balance weighing machine (Libra; Made in India) to the nearest $0.5 \mathrm{~kg}$. Height was measured using anthropometric rod (Galaxy International; New Delhi, Made in India) to the nearest $0.1 \mathrm{~cm}$. The BMI was computed following internationally accepted standard equation as weight (in $\mathrm{kg}$ ) divided by square of height (in meters), as follows BMI-Weight $(\mathrm{kg}) /$ Height $\left(\mathrm{m}^{2}\right)$ (Waterlow 1977). The data was analyzed using SPSS version 16 and MS-Excel software. Distance curve of Body Mass Index were plotted against age (Figure1). BMI status was evaluated by direct use of the new international graded definition of thinness in childhood and adolescence (Cole et al.2007; Virani 2010; Khadilkar et al.2012), based on WHO recommended cut off points (WHO 2006; Dietz et al.1998; IOTF 1998; Hosseini 1999).

\begin{tabular}{|c|c|c|c|c|c|}
\hline Age & $\begin{array}{c}\text { Boys Height } \\
\text { Mean }\end{array}$ & $\begin{array}{c}\text { S.D. of Boys } \\
\text { Height }\end{array}$ & $\begin{array}{c}\text { Girls Height } \\
\text { Mean }\end{array}$ & $\begin{array}{c}\text { S.D. of Girls } \\
\text { Height }\end{array}$ & T- Test \\
\hline $6+$ & 105.56 & \pm 3.4 & 103.57 & \pm 5.3 & 0.14432 \\
\hline $7+$ & 110.90 & \pm 2.4 & 110.35 & \pm 2.3 & 0.45648 \\
\hline $8+$ & 115.04 & \pm 3.3 & 115.33 & \pm 2.0 & 0.73859 \\
\hline $9+$ & 123.11 & \pm 2.8 & 122.40 & \pm 4.4 & 0.54379 \\
\hline $10+$ & 125.80 & \pm 3.2 & 125.22 & \pm 4.9 & 0.64431 \\
\hline $11+$ & 128.39 & \pm 2.3 & 131.02 & \pm 5.9 & 0.03033 \\
\hline $12+$ & 135.74 & \pm 5.2 & 132.13 & \pm 5.8 & 0.01377 \\
\hline $13+$ & 141.17 & \pm 4.8 & 142.91 & \pm 3.1 & 0.11005 \\
\hline $14+$ & 150.20 & \pm 5.6 & 144.50 & \pm 2.8 & 3.51708 \\
\hline $15+$ & 156.21 & \pm 5.4 & 145.98 & \pm 1.6 & 5.09271 \\
\hline $16+$ & 159.70 & \pm 5.5 & 148.17 & \pm 3.6 & 5.02204 \\
\hline $17+$ & 160.45 & \pm 5.1 & 151.81 & \pm 3.5 & 2.43611 \\
\hline $18+$ & 164.43 & \pm 2.8 & 148.29 & \pm 2.3 & 5.53647 \\
\hline
\end{tabular}

Table - 1: Height of Bhotia boys and girls: A descriptive statistics.

\begin{tabular}{|c|c|c|c|c|c|}
\hline Age & $\begin{array}{c}\text { Boys Weight } \\
\text { Mean }\end{array}$ & $\begin{array}{c}\text { S.D. of Boys } \\
\text { weight }\end{array}$ & $\begin{array}{c}\text { Girls Weight } \\
\text { Mean }\end{array}$ & $\begin{array}{c}\text { S.D. of Girls } \\
\text { Weight }\end{array}$ & T- Test \\
\hline $6+$ & 16.54 & 1.4 & 16.21 & 2.2 & 0.56100 \\
\hline $7+$ & 17.86 & 1.4 & 18.50 & 1.4 & 0.15018 \\
\hline $8+$ & 21.40 & 1.9 & 19.90 & 1.2 & 0.00516 \\
\hline $9+$ & 23.45 & 1.6 & 22.83 & 2.5 & 0.35115 \\
\hline $10+$ & 24.51 & 2.0 & 24.88 & 2.4 & 0.57723 \\
\hline $11+$ & 27.74 & 1.7 & 27.34 & 3.4 & 0.57991 \\
\hline $12+$ & 30.88 & 2.4 & 28.11 & 3.0 & 0.00028 \\
\hline $13+$ & 35.15 & 2.3 & 37.74 & 3.6 & 0.00286 \\
\hline $14+$ & 40.74 & 3.6 & 44.33 & 2.0 & 4.03165 \\
\hline $15+$ & 46.83 & 2.4 & 45.52 & 1.7 & 0.02622 \\
\hline $16+$ & 49.53 & 2.3 & 45.20 & 2.2 & 2.63261 \\
\hline $17+$ & 51.63 & 2.7 & 46.91 & 1.7 & 4.42221 \\
\hline $18+$ & 50.76 & 3.0 & 47.45 & 1.5 & 5.75546 \\
\hline
\end{tabular}


Table - 2: Descriptive statistics for weight of Bhotia boys and girls.

\begin{tabular}{|c|c|c|c|}
\hline Age & Boys BMI Mean & Boys BMI Mean & T- Test \\
\hline $6+$ & 14.84351 & 15.11868 & 0.43408 \\
\hline $7+$ & 14.52588 & 15.19117 & 0.01687 \\
\hline $8+$ & 16.16582 & 14.96522 & 0.00184 \\
\hline $9+$ & 15.47360 & 15.24075 & 0.30801 \\
\hline $10+$ & 15.48624 & 15.86538 & 0.18508 \\
\hline $11+$ & 16.83037 & 15.92842 & $4.0288 \mathrm{E}$ \\
\hline $12+$ & 16.76102 & 16.10000 & 0.00160 \\
\hline $13+$ & 17.63848 & 18.48177 & 0.00787 \\
\hline $14+$ & 18.05768 & 21.22819 & 3.55766 \\
\hline $15+$ & 19.19005 & 21.35953 & 3.07835 \\
\hline $16+$ & 19.41921 & 20.58949 & 0.00063 \\
\hline $17+$ & 20.05477 & 20.35253 & 0.30835 \\
\hline $18+$ & 18.77444 & 21.57655 & 4.38007 \\
\hline
\end{tabular}

Table - 3: BMI of Bhotia boys and girls: A descriptive statistics.

\section{RESULT:}

Bhotia children are apparently healthy and normal, However, There are significant difference in height and weight data's of the Bhotia children across the age groups $(\mathrm{p}<0.05)$. As can be seen in Table-4, 20.6 percent children (6.84 percent boys and 13.03 percent girls) are having thinness grade one, among boys, 0.3 percent were identified with grade two and grade three thinness, direct use of age and sex specific BMI of Asian adult at the age of 18 years have shown that 88.69 percent boys and 75.24 percent girls are normal and only 3.86 percent boys and 11.72 percent girls are overweight, no case of obesity was found among both the sexes. Significant sexual difference has been found for the BMI between boys and girls except age group of seven, eight, nine, twelve, thirteen and sixteen, where as there is no significant difference have been found between boys and girls body mass index.

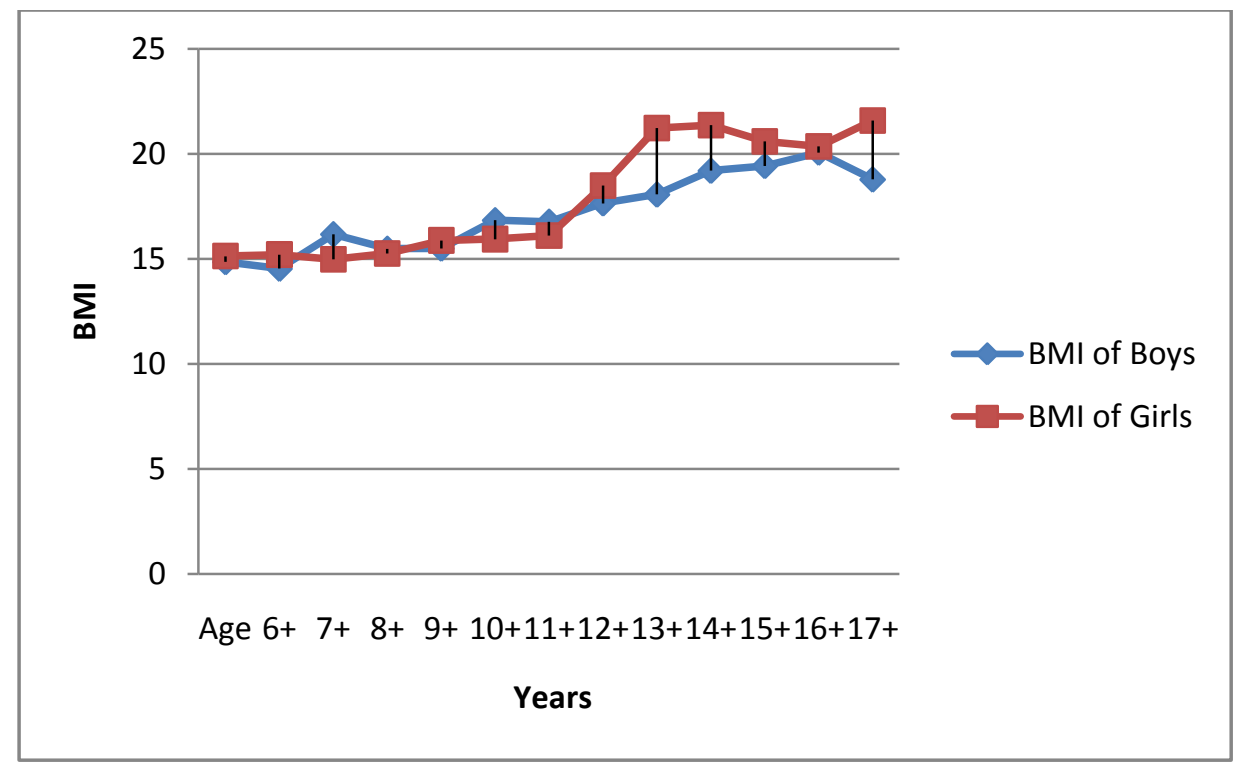

Figure -1: Distance curve for Body Mass Index of Bhotia Boys and Girls. 


\section{DISCUSSION:}

The present cross-sectional study was conducted in Uttarakhand, the northern province of India among the Bhotia tribal children. Aim of this study was to see nutritional health status based on age-sex specific BMI status of Bhotia children by using new graded definition of thinness and overweight based on pooled international data for BMI. Indian children are suffering from double burden diseases (WHO 2012), on one hand under nutrition are highly prevalent and on the other overweight related dieses are also knocking the door in metro cities and even high income group families.

Bhotias lived in high altitude of the mountainous region where supplies of nutritious and surplus food through out the year is very difficult. High percentage of grade-III thinness was observed among both girls as well as boys. Table-4 show that Bhotia children have shown grade one and two $(0.29 \%)$ thinness which is a sever grade of thinness, were found only among the boys. Girls made better use of their provided foods and put on subcutaneous fat on their body this may be because of the advantageous double $\mathrm{x}$ gene of the girl child. Therefore, some frequency of overweight was found among girls, Dutta and Pant (2003) has also got similar findings from the indigenous population of the same settings (Garhwal Himalyas).

\begin{tabular}{|ccccc|}
\hline Cut-off points & Boys Frequency & Percentage & Girls Frequency & Percentage \\
\hline Thinness grade 3 & 23 & 6.84 & 40 & 13.02 \\
\hline Thinness grade 2 & 01 & 0.29 & 00 & 0.0 \\
\hline Thinness grade 1 & 01 & 0.29 & 00 & 0.0 \\
\hline Normal & 298 & 88.69 & 231 & 11.72 \\
\hline Overweight & 13 & 3.86 & 36 & 0.0 \\
\hline Obesity & 00 & 0.00 & 00 & 100 \\
\hline Total & 336 & 100 & 307 & \\
\hline
\end{tabular}

Table - 4: Distribution of Bhotia children in various BMI grades.

\section{CONCLUSION}

Present study revealed that most of the Bhotia Children 88.69 percent Boys and 75.24 percent girls are normal and nutritionally healthy according to their Body Mass Index. There is some prevalence of overweight found among girls, but 13.02 percent girls and 7.42 percent boys are thin, however, grade one and two thinness $(0.29 \%)$ was also found only among the boys, no case of obesity was observed among Bhotia children. Study also indicates that girls have a trend of puting weight on late adolescence where as the boys continue to be thin at their adolescence.

\section{REFERENCES:}

[1] Atkinson, Edwin T. 1884. Himalayan Districts of the North-Western Provinces of India, (3Vol) Allahabad.

[2] Brown C W. 1987. Ecology, Trade and Former Bhotia Identity, The Himalayan Heritage; Ed Raha M K, 125-38.

[3] Cole TJ, Bellizzi MC, Flegal KM \& Dietz WH. 2000. Establishing a standard definition for child overweight and obesity: International survey. Br Med J. 320: 1240-3.

[4] Cole TJ, Flegal KM, Nicholls D, Jackson AA. 2007. Body mass index cut offs to define thinness in children and adolescents: International survey. Br Med J. 335: 194-2002.

[5] Cole TJ. 1991. Weight-stature indices to measure underweight, overweight and obesity. In: Himes JH, ed. Anthropometric assessment of nutritional status. New York: Wiley-Liss,83-111.

[6] Dabral S P. 2022(Vikrami).Uttarakhand ka Itihas (Hindi) Dogadda, Garhwal.

[7] Dietz WH, Robinson TN. 1998. Use of the body mass index as a measure of overweight in children and adolescents. J Pediatr. 132:191-193. 
[8] Dutta A, Pant K. 2003. The Nutritional Status of Indigenous People in the Garhwal Himalaya, India. Mountain Research and Development, Vol-23, No 3, August, 278-83.

[9] Gadzik, James. 2006. "How much should I weigh?' Quetelet's equation, upper weight limits, and BMI prime". Connecticut Medicine. 70 (2): 81-88.

[10] Hosseini M, Carpenter RG, Mohammad K. 1999. Standardized percentile curves of body mass index of Iranian children compared to the US population reference. Int J Obese Relat Metab Discords , 23 (8): 783-7.

[11] Jiang YF,Ju MF,Lin ZF, Dong XY, Zhang L. 2006. Body mass index percentile curves and cut off points for assessment of overweight and obesity in Shanghai children World J Pediatr, Vol 2 No 1:35-39.

[12] Khadilkar VV, Khadilkar AV, Borade AB, Chiplonkar SA. 2012. Body Mass Index Cut off points for Screening for Childhood Overweight and Obesity in Indian Children, Indian Pediatr. 49:29-34.

[13] Khongsdier R, and Mukherjee N. 2003. Effects of Heterosis on Growth in Height, and its Segments: A Cross-Sectional Study of the Khasi Girls in Northeast India. Ann. Of Hum. Biol. a, 30: 605-621.

[14] Maikhuri R K, Nautiyal S, Rao K S, Saxena K G. 1998. Medicinal plant cultivation and biosphere reserve management: A case study from the Nanda Devi Biosphere Reserve, Himalaya. Current Science, Vol 74, No 2, January, 157-63.

[15] Malina RM, Katzmarzyk PT. 1999. Validity of the body mass index as an indicator of the risk and presence of overweight in adolescents. Am J Clin Nutr. 70:131-36.

[16] McMurray, C. 1996. "Cross-sectional anthropometry: What can it tell us about the health of young children?" Health Transition Review, No. 6, pp. 147-168.

[17] (a) Nautiyal S, Maikhuri R K, Rao K S , Saxena K G. 2003. Ethno botany of the Tolchha Bhotia tribe of the buffer zone village in Nanda Devi biosphere Reserve, India, Scientific Publishers(India), J. Econ. Taxon. Bot. Vol.27 No.1, 119-42.

(b) Nautiyal S, Rao K S, Maikhuri R K, Saxena K G. 2003. Transhumant pastoralism in the Nanda Devi Biosphere Reserve, India, A case study in the buffer zone, Mountain Research and Development, Vol-23, No 3, August. 255-62.

[18] Negi R S. 1995. Population Dynamics of Central \& Western Himalaya. The People of Himalaya, EdRaha, M K.

[19] Purohit A, Maikhuri R K, Rao K S, Nautiyal S. 2002. Revitalizing drink: An assessment of traditional knowledge system in Bhotia community of Central Himalayas, India; Indian journal of Traditional knowledge, Vol 1, No 1, October, 72-80.

[20] Virani N. 2010. Reference curves and cut-off values for anthropometric indices of adiposity of affluent Asian Indian children aged 3-18 years. Ann Hum Biol. Early Online: 1-13.

[21] Waterlow JC, Buzina R, Keller W, Lane JM, Nichaman MZ, Tanner JM. 1977. The presentation and use of height and weight data for comparing the nutritional status of groups of children under the age of 10 years. Bull World Health Organ. 55:489-98.

[22] Weiner, J. S. and Lourie, J. A. 1981. Practical Human Biology. Academic Press London.

[23] WHO Expert Consultation. 2004. Appropriate body-mass index for Asian populations and its implications for policy and intervention strategies. Lancet. 363:157-163.

[24] WHO, Geneva. 1998. International Obesity Task Force. Obesity: preventing and managing the global epidemic. Report of WHO consultation on obesity, Geneva, 3-5 June.

[25] WHO. 1995. Physical status: the use and interpretation of anthropometry. Report of a WHO Expert Committee. Tech Rep Ser. 854:1-452.

[26] WHO. 2006. Child growth standards: length/height-forage, weight-for-age, weight-for-length, weight-for height and body mass index-for-age: methods and development. Geneva. 